\title{
A Further Study of the Metabolic Buffer Value and the Bohr Effect in Human Fetal Whole Blood
}

\author{
WANdA ArgZynska ${ }^{[13]}$ \\ Service de Pédiatrie, Hôpital Cantonal Universitaire, Lausanne, Switzerland
}

\begin{abstract}
Extract
The metabolic buffer value $\left(\lambda=\Delta \mathrm{H}^{+} /\right.$liter $\cdot \mathrm{pH}$ unit $)$ and the Bohr effect $\left(-\Delta \mathrm{H}^{+} /\right.$ $\left.\Delta \mathrm{O}_{2}\right)$ were studied in vitro in fetal blood at a base excess concentration [BE] of $0 \mathrm{mEq} /$ liter and $+10 \mathrm{mEq} /$ liter by the same method as in a previous study [3]. At a $\mathrm{P}_{\mathrm{CO}_{2}}$ of 30,40 , and $60 \mathrm{~mm} \mathrm{Hg}$, the mean fetal $\lambda( \pm \mathrm{SEM})$ was, respectively, for [BE] $=0 \mathrm{mEq} /$ liter: $74.00 \pm 2.01,79.00 \pm 1.35$, and $87.75 \pm 2.42 \mathrm{mEq} \mathrm{H}+/$ liter $\cdot \mathrm{pH}$ unit; for [BE] $=+10 \mathrm{mEq} /$ liter: $96.75 \pm 3.24,97.50 \pm 3.85$, and $103.75 \pm 8.17 \mathrm{mEq} \mathrm{H}+/$ liter $\cdot \mathrm{pH}$ unit. At $\mathrm{P}_{\mathrm{CO}_{2}}$ of 30,40 , and $60 \mathrm{~mm} \mathrm{Hg}$, the mean fetal Bohr effect ( \pm SEM) was respectively, for $[\mathrm{BE}]=0 \mathrm{mEq} /$ liter: $0.447 \pm 0.021,0.469 \pm 0.023$, and $0.505 \pm 0.027$ $\mathrm{mEq} \mathrm{H}+/ \mathrm{mM} \mathrm{O}_{2}$; for $[\mathrm{BE}]=+10 \mathrm{mEq} /$ liter: $0.36 \mathrm{l} \pm 0.033,0.395 \pm 0.032$, and $0.467 \pm 0.051 \mathrm{mEq} \mathrm{H}+/ \mathrm{mM} \mathrm{O}_{2}$. These values together with the previous results obtained at $[\mathrm{BE}]=-9 \mathrm{mEq} /$ liter were compared with the corresponding values obtained previously for adult blood with the same conditions and method. This comparison between adult and fetal blood demonstrates that the $\mathrm{pH}$-dependent variation of $\lambda$ is more marked, at low $\mathrm{P}_{\mathrm{CO}_{2}}$, in fetal blood than in adult blood, and the relation between the plasma $\mathrm{pH}$ and the Bohr effect is different in fetal blood compared with adult blood.
\end{abstract}

\section{Speculation}

The present study makes apparent some differences between fetal and adult blood in regard to the buffering properties and the Bohr effect. These results are difficult to interpret in term of physicochemical properties of fetal hemoglobin; however, the following practical implications result from the present data. (1) The [BE] scale of the Siggaard-Andersen nomogram is not strictly adequate for fetal blood in vitro in alkaline $\mathrm{pH}$ range. (2) Because the $-\Delta \mathrm{H}^{+} / \Delta \mathrm{O}_{2}$ ratio is greater in fetal blood than in adult blood, the results obtained by the Astrup method for desaturated fetal blood must be corrected in accordance with the desaturation level.

\section{Introduction}

The differences in quality and in quantity of hemoglobin in fetal blood in regard to adult blood prompted us to determine and compare the buffer values and the Bohr effect of human fetal and adult blood. A study of these variables made in adult and fetal blood at the original acid state of fetal blood, i.e., at a $[\mathrm{BE}]$ of -9 $\mathrm{mEq} /$ liter, showed that the metabolic buffer value $(\lambda$ $=\mathrm{mEq} \mathrm{H}+/$ liter $\cdot \mathrm{pH}$ unit) and the Bohr effect $\left(-\Delta \mathrm{H}^{+} / \Delta \mathrm{O}_{2}=\mathrm{mEq} \mathrm{H}^{+} / \mathrm{mM} \mathrm{O}_{2}\right)$ were similar in fetal and adult blood [3]. However, it has been demonstrated in adult whole blood that the $\lambda$ and the 
$-\Delta \mathrm{H}+/ \Delta \mathrm{O}_{2}$ ratio depend at any constant $\mathrm{P}_{\mathrm{CO}_{2}}$ on the $\mathrm{pH}$, i.e., on the [BE]; a rise of $\mathrm{pH}$ at constant $\mathrm{P}_{\mathrm{CO}_{2}}$ causes an increase of $\lambda$ and a decrease of the $\Delta \mathrm{H}^{+} / \Delta \mathrm{O}_{2}$ ratio $[6,10]$. Thus, it is interesting to determine these variables in fetal blood at different levels of $[\mathrm{BE}]$. In this study the fetal blood was alkalized in order to obtain $[\mathrm{BE}]=0$ and $+10 \mathrm{mEq} /$ liter and the $\lambda$ and the $-\Delta \mathrm{H}^{+} / \Delta \mathrm{O}_{2}$ ratio was determined at three different $\mathrm{P}_{\mathrm{CO}_{2}}$ and compared with the adult values obtained under the same conditions. This comparison brings out the following differences between adult and fetal blood: ( 1 ) the $\mathrm{pH}$-dependent variation of $\lambda$ is more marked, at low $\mathrm{P}_{\mathrm{CO}_{2}}$, in fetal blood than in adult blood; (2) the relation between the plasma $\mathrm{pH}$ and the Bohr effect is different in fetal blood compared with adult blood.

\section{Methods}

Blood from full term fetuses was obtained at delivery by punture of a cord vessel before separation of the placenta; this blood was immediately alkalized by addition of isotonic $\mathrm{NaHCO}_{3}$. In order to obtain a [BE] of $0 \mathrm{mEq} /$ liter, $1 \mathrm{ml}$ solution containing $160 \mathrm{mEq} / \mathrm{li}$ ter $\mathrm{NaHCO}_{3}$ (301 mOsmol/liter) was slowly mixed in vitro with $15 \mathrm{ml}$ fresh heparinized fetal blood. Two milliliters of the same solution were added in the same manner to $15 \mathrm{ml}$ fetal blood in order to obtain a [BE] of $+10 \mathrm{mEq} /$ liter. After this alkalization, each blood sample was immediately handled as previously described [3]. All procedures were identical with those previously reported $[2,3]$.

\section{Results}

Ten experiments were performed on fetal blood in vitro at a [BE] of $0 \mathrm{mEq} /$ liter and 10 at a $[\mathrm{BE}]$ of +10 $\mathrm{mEq} /$ liter. For each $[\mathrm{BE}]$ and at three different $\mathrm{P}_{\mathrm{CO}_{2}}$ levels $(30,40$, and $60 \mathrm{~mm} \mathrm{Hg})$, the following variables were studied: (l) the $\mathrm{pH}$ of saturated blood at each $\mathrm{P}_{\mathrm{CO}_{2}}\left(\mathrm{pH}_{\mathrm{ox}}\right),(2)$ the change of $\mathrm{pH}$ caused by the complete oxygenation of a desaturated blood sample at a constant $\mathrm{P}_{\mathrm{CO}_{2}}\left(\Delta \mathrm{pH}_{\mathrm{ox} \text {-red }}\right)$, (3) the metabolic buffer value $(\lambda),(4)$ the Bohr effect $\left(-\Delta \mathrm{H}^{+} / \Delta \mathrm{O}_{2}\right)$. The mean values ( \pm SEM) are represented on Table I; for the purpose of comparison, the mean adult values ob-

Table $I$. Mean values ( \pm SEM) for fetal blood $(n=10)$ and for adult blood $(n=9)$

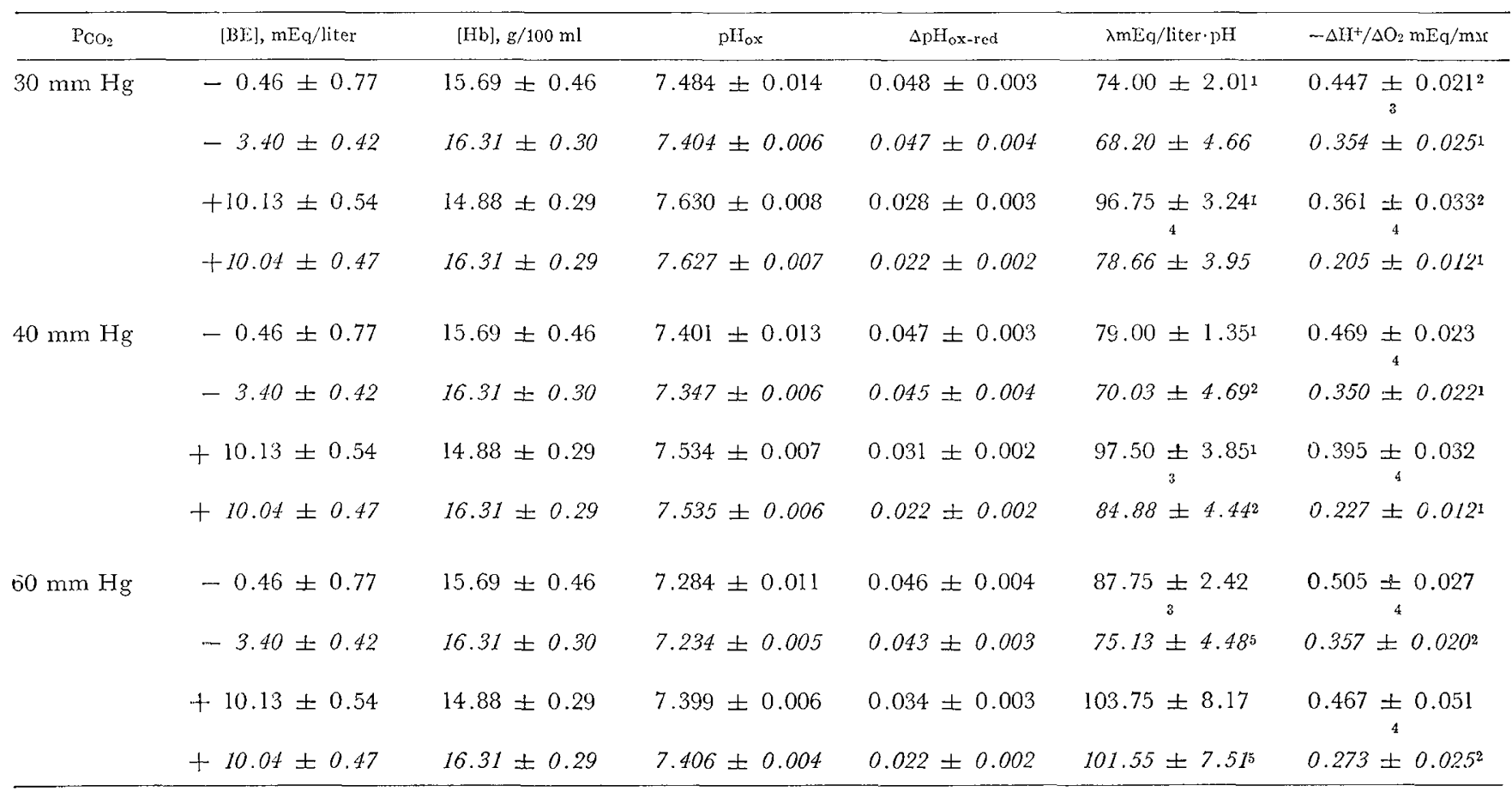

${ }^{1}$ Student $t$ test: $[\mathrm{BE}] 0-[\mathrm{BE}]+10: P<0.001$.

${ }^{2}$ Student $t$ test: $[\mathrm{BE}] 0-[\mathrm{BE}]+10: P<0.05$.

${ }^{3}$ Student $t$ test: adult-fetal: $P<0.05$.

${ }^{4}$ Student $t$ test: adult-fetal: $P<0.005$.

${ }^{5}$ Student $t$ test: $[\mathrm{BE}] 0-[\mathrm{BE}]+10: P<0.01$. 


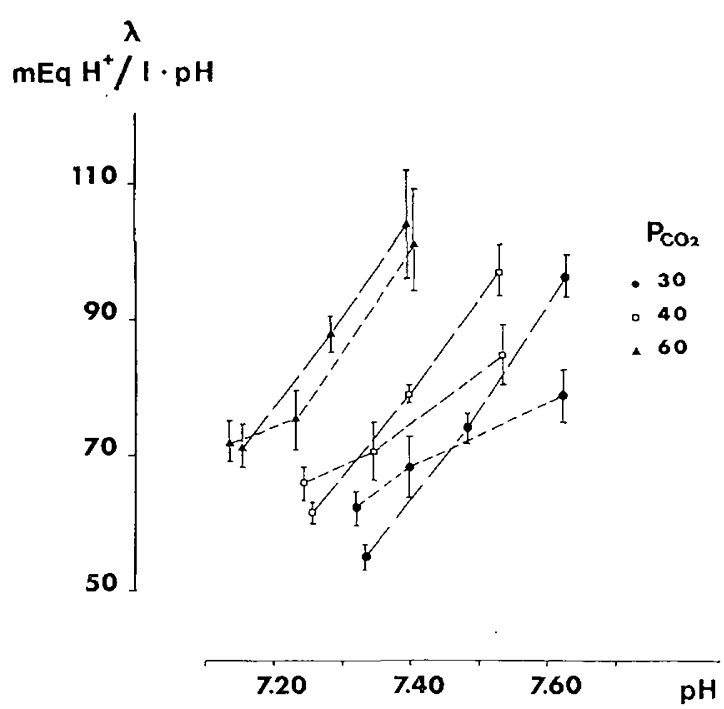

Fig. 1. Relation between the metabolic buffer value $(\lambda)$ and the $\mathrm{pH}$ at three different $\mathrm{P}_{\mathrm{CO}_{2}}$ in adult $(---)$ and fetal $(--)$ blood.

tained in previous studies in the same conditions $[2,6]$ are set in italics.

Figure 1 shows the relation between the mean $\lambda$ and the $\mathrm{pH}$ at $\mathrm{P}_{\mathrm{CO}_{2}} 30,40$, and $60 \mathrm{~mm} \mathrm{Hg}$. The values obtained previously for adult and fetal blood [3] at $[\mathrm{BE}]=-9 \mathrm{mEq} /$ liter are included on this graph together with the values of Table $I$. This diagram makes apparent the following. At $\mathrm{P}_{\mathrm{CO}_{2}} 30 \mathrm{~mm} \mathrm{Hg}$ the fetal $\lambda$ is significantly lower than the adult $\lambda$ in an acid $\mathrm{pH}$ range, whereas fetal $\lambda$ becomes significantly greater than the adult $\lambda$ in an alkaline $\mathrm{pH}$ range. At $\mathrm{P}_{\mathrm{CO}_{2}} 40$ mm $\mathrm{Hg}$ no differences can be demonstrated between fetal and adult $\lambda$ in acid $\mathrm{pH}$ range, but the fetal $\lambda$ is also greater than the adult $\lambda$ in an alkaline $\mathrm{pH}$ range. At $\mathrm{P}_{\mathrm{CO}_{2}} 60 \mathrm{~mm} \mathrm{Hg}$, the fetal and adult $\lambda$ are not significantly different at each $\mathrm{pH}$ level.

Figure 2 represents the mean change of $[\mathrm{BE}](\Delta[\mathrm{BE}])$ after the addition of known amounts of base to 10 fetal blood samples in vitro, at an initial [BE] of either 0 or $+10 \mathrm{mEq} /$ liter. The $\Delta[\mathrm{BE}]$ was read on the base excess scale of the Siggaard-Andersen nomogram [9]. Figure 2 indicates that the $\Delta[\mathrm{BE}]$ is lower than the true amount of base added. This relation can be expressed by the following equation: $\Delta[\mathrm{BE}]$ (milliequivalents per liter) $=0.88 \cdot$ base added (milliequivalents per liter). The coefficient of 0.88 is valid for an initial [BE] of either 0 or $+10 \mathrm{mEq} /$ liter.

The relation between the $\mathrm{pH}$ and the Bohr effect is shown in Figure 3 for adult and fetal blood at $\mathrm{P}_{\mathrm{CO}_{2}} 30$, 40 , and $60 \mathrm{~mm} \mathrm{Hg}$. As in Figure 1, the adult and fetal values for $[\mathrm{BE}]=-9 \mathrm{mEq} /$ liter are included from the previous study [3]. The values obtained at three different [BE] at constant $\mathrm{P}_{\mathrm{CO}_{2}}$ were linked by dashed straight lines (- - ). This graph demonstrates several differences between the adult and the fetal Bohr effect. (1) At any constant $\mathrm{P}_{\mathrm{CO}_{2}}$, the adult $-\Delta \mathrm{H}^{+} / \Delta \mathrm{O}_{2}$ ratio decreases regularly when the $\mathrm{pH}$ increases. In fetal blood, the $-\Delta \mathrm{H}+/ \Delta \mathrm{O}_{2}$ ratio first increases when the $\mathrm{pH}$ increases to a given value for each $\mathrm{P}_{\mathrm{CO}_{2}}$. A further increase of $\mathrm{pH}$ then results in a decrease of the ratio.

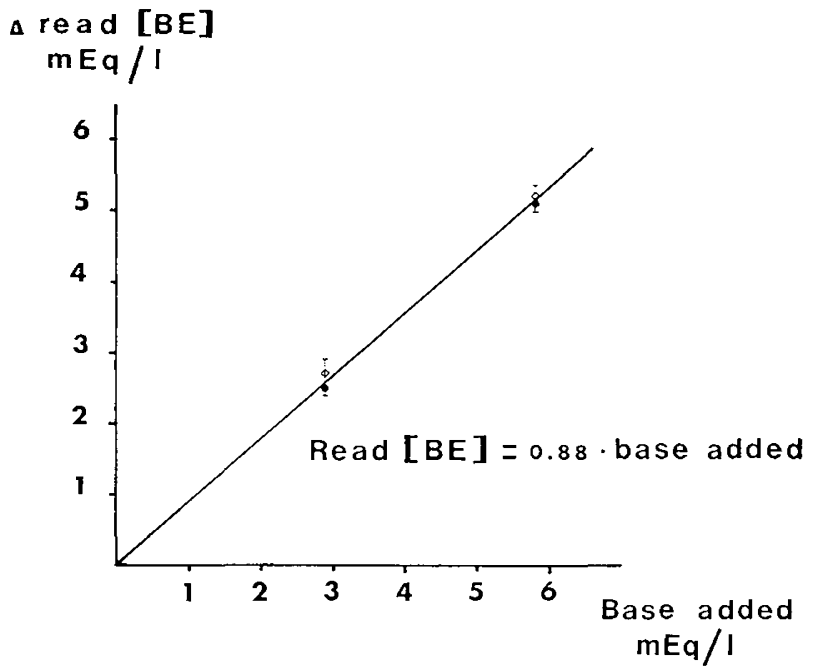

Fig. 2. Relation between the change of $\mathrm{BE}$ obtained on the Siggaard-Andersen nomogram and the actual amount of base added in fetal blood. $\bullet[\mathrm{BE}]$ initial: $0 \mathrm{mEq} /$ liter; $\diamond[\mathrm{BE}]$ initial: $+10 \mathrm{mEq} /$ liter.

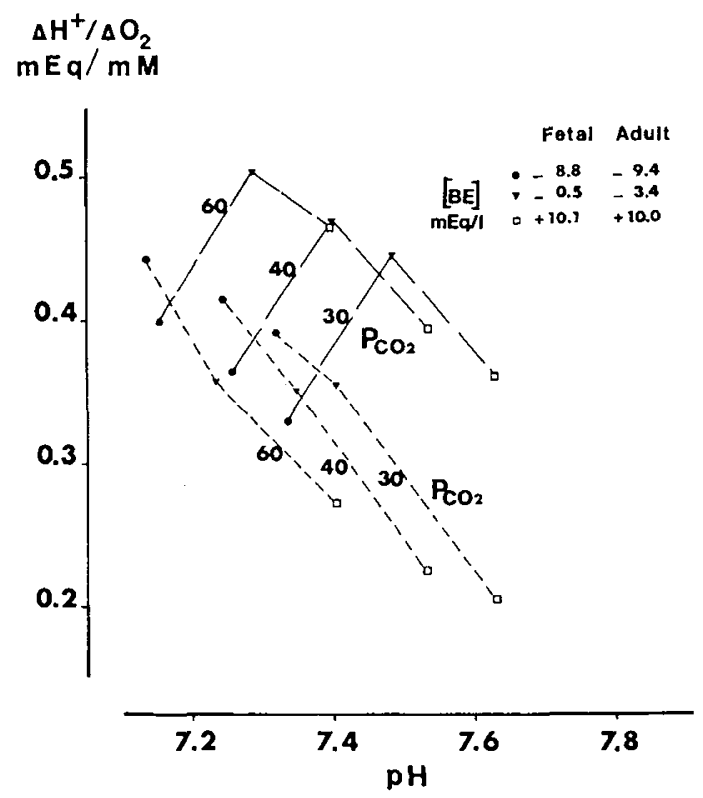

Fig. 3. Relation between the Bohr effect and the $\mathrm{pH}$ at three different $\mathrm{P}_{\mathrm{CO}_{2}}$ in adult (--) and fetal (- $\longrightarrow$ ) blood. 
(2) At $[\mathrm{BE}]=-9 \mathrm{mEq} /$ liter, the fetal and adult Bohr effects are similar at each $\mathrm{P}_{\mathrm{CO}_{2}}$, whereas at $[\mathrm{BE}]=0$ and $+10 \mathrm{mEq} /$ liter, the fetal ratios are significantly greater than the adult ratios at each $\mathrm{P}_{\mathrm{CO}_{2}}$ (cf. Table $\mathrm{I}$ ). (3) At any constant $\mathrm{pH}$, adult Bohr effect is greater at low $\mathrm{P}_{\mathrm{CO}_{2}}$ than at high $\mathrm{P}_{\mathrm{CO}_{2}}$. In contrast, fetal Bohr effect at constant $\mathrm{pH}$ is lower at low $\mathrm{P}_{\mathrm{CO}_{2}}$ than at high $\mathrm{P}_{\mathrm{CO}_{2}}$, at least in the $\mathrm{pH}$ range below 7.4.

\section{Discussion}

\section{Metabolic Buffer Value}

Although the fetal $\lambda$ value was similar or even smaller than the adult $\lambda$ in an acidotic range ([BE] $=$ $-9 \mathrm{mEq} /$ liter) [3], it appears from the present results that the fetal $\lambda$ becomes significantly greater than the adult $\lambda$ in alkaline conditions $([\mathrm{BE}]=+10 \mathrm{mEq} / \mathrm{li}$ ter). Figure I shows clearly the difference of evolution of the $\lambda$ according to the $\mathrm{pH}$ in fetal blood compared with adult blood. This dissimilarity between adult and fetal $\lambda$ in the alkaline range can be due to differences in both buffer systems of whole blood, i.e., the bicarbonate-carbonic acid system or the noncarbonic buffers. The difference in fetal $\lambda$ compared with adult $\lambda$ observed at $\mathrm{P}_{\mathrm{CO}_{2}} 60 \mathrm{~mm} \mathrm{Hg}$ for a respective [BE] of 0 and $-3.4 \mathrm{mEq} /$ liter may be an artifact, since the fetal plasma $\mathrm{pH}\left(\mathrm{pH}_{\mathrm{p}}\right)$ was greater than the adult $\mathrm{pH}_{\mathrm{p}}$ (Table I). Thus, the concentration of plasma $\mathrm{HCO}_{3}{ }^{-}$ is greater in fetal than in adult blood and this fact may explain the greater fetal $\lambda$. At a $[\mathrm{BE}]$ of +10 $\mathrm{mEq} /$ liter, this explanation cannot account for the greater $\lambda$ in fetal blood than in adult blood observed at $\mathrm{P}_{\mathrm{CO}_{2}} 30$ and $40 \mathrm{~mm} \mathrm{Hg}$. As $\mathrm{pH}_{\mathrm{p}}$ is the same in adult and fetal blood at each $\mathrm{P}_{\mathrm{CO}_{2}}$, the plasma bicarbonate concentration is identical in both. A greater amount of hemoglobin $(\mathrm{Hb})$ in fetal blood than in adult blood could be responsible for the greater fetal $\lambda$, but as shown on Table $\mathrm{I}$, the $\mathrm{Hb}$ concentration is lower in fetal blood than in adult blood because of the dilution caused by the alkalization. This difference in hematocrit is not sufficient to cause a blood $\mathrm{HCO}_{3}$ - concentration greater in fetal than in adult blood. Because the carbonic buffers are not responsible for the difference between fetal $\lambda$ and adult $\lambda$, a different quality of the noncarbonic buffers in fetal blood must be postulated. Inasmuch as the $\lambda$ was measured on fully oxygenated blood, one can propose that the oxygenated fetal $\mathrm{Hb}$ $(\mathrm{HbF})$ is a better buffer than the oxygenated adult $\mathrm{Hb}$ $(\mathrm{HbA})$, at least at low $\mathrm{P}_{\mathrm{CO}_{2}}$ in $\mathrm{pH}$ range above 7.5 . The superior buffering capacity of $\mathrm{HbF}$ could be due to differences in the pK of some groups of the $\gamma$-globin chain of $\mathrm{HbF}$ in regard to the $\beta$-globin chain of $\mathrm{HbA}$. Differences in carbamino compounds do not seem to be involved, because Bauer and Schröder [5] determined that the same amount of $\mathrm{CO}_{2}$ was bound to fetal $\mathrm{HbO}_{2}$ as to adult $\mathrm{HbO}_{2}$. Studies of the buffer value of $\mathrm{HbF}$ in solutions at various $\mathrm{P}_{\mathrm{CO}_{2}}$ and 2,3-diphosphoglycerate levels would be useful in order to explain the present results. Although the underlying causes of this high $\lambda$ in fetal blood in alkaline conditions cannot be elucidated with the available data, a practical consequence arises from this difference between adult and fetal buffering properties. As shown on Figure 2, a discrepancy exists between the change of $[\mathrm{BE}]$ obtained from the BE scale of the Siggaard-Andersen nomogram and the actual amount of base added, when the fetal blood is titrated in an alkaline $\mathrm{pH}$ range. The $\mathrm{BE}$ scale was constructed from values of adult blood [8]. Therefore, the greater $\lambda$ in fetal blood compared with adult blood in alkaline range results in nomogram [BE] values lower than the true [BE]. As previously reported [3], the BE scale is accurate for fetal blood in an acid $\mathrm{pH}$ range.

\section{Bohr Effect}

The present study demonstrates some differences between the Bohr effects of fetal and adult whole blood, which were similar in an acid $\mathrm{pH}$ range. Indeed as in adult blood, the fetal $-\Delta \mathrm{H}+/ \Delta \mathrm{O}_{2}$ ratio is $\mathrm{pH}$ - and $\mathrm{P}_{\mathrm{CO}_{2}}$-dependent but the shapes of the dependence are unlike in fetal and in adult blood (Fig. 3). It may be emphasized that the adult values are, in the range of pH studied, in good agreement with the results obtained under similar conditions by Siggaard-Andersen [10]. Thus, the magnitude of the Bohr effect in adult whole blood and its relation with $\mathrm{P}_{\mathrm{CO}_{2}}$ and $\mathrm{pH}$ could be explained at least qualitatively by the effects of the carbamino compounds in $\mathrm{Hb}$ solutions [7] and by the simultaneous effects of 2,3-diphosphoglycerate reported by several authors in $\mathrm{HbA}$ solutions or in whole blood $[4,10]$.

In fetal blood the interpretation of the present results in accordance with the facts observed in $\mathrm{HbF}$ solutions or in fetal erythrocytes is difficult. According to the work of Antonini et al. [1] on $\mathrm{Hb}$ solutions in absence of $\mathrm{CO}_{2}$, the $-\Delta \mathrm{H}^{+} / \Delta \mathrm{O}_{2}$ ratio is the same in $\mathrm{HbF}$ solutions as in $\mathrm{HbA}$ solutions, at least for the $\mathrm{pH}$ range from 6.5 to 9.0. Bauer and Schröder [5] demonstrated that the amount of oxylabile carbaminos compounds is higher in fetal than in adult erythrocytes at intraerythrocytic $\mathrm{pH}\left(\mathrm{pH}_{\mathrm{i}}\right)$ from 7.0 to 7.5 [5]. Thus the fetal $\Delta \mathrm{H}^{+} / \Delta \mathrm{O}_{2}$ ratio should be smaller than the 
adult ratio in this range of $\mathrm{pH}_{\mathrm{i}}$, at least when the Bohr effect is measured inside the erythrocyte. When the determinations are made in whole blood at constant $\mathrm{pH}_{\mathrm{p}}$, the variations of $\mathrm{pH}_{\mathrm{i}}$ which occur during oxygenation influence the measured values $[6,10]$. Indeed, a decrease of $\mathrm{pH}_{\mathrm{i}}$ at constant $\mathrm{pH}_{\mathrm{p}}$ means that a given amount of protons has been titrated inside the erythrocyte. This amount depends on the buffer value of the erythrocyte content and on the $\mathrm{pH}_{\mathrm{i}}$ according to the classic equation: $\Delta \mathrm{H}^{+}=\Delta \mathrm{pH}_{\mathrm{i}} \cdot$ buffer value $(\lambda)$. According to the data of Bauer and Schröder [5], the $\mathrm{pH}_{\mathrm{i}}$-decrease occurring during oxygenation at a constant $\mathrm{pH}_{\mathrm{p}}$ of 7.4 and at a $\mathrm{P}_{\mathrm{CO}_{2}}$ of $40 \mathrm{~mm} \mathrm{Hg}$, is 0.047 for adult erythrocytes and 0.038 for fetal erythrocytes. For an intraerythrocytic buffer value which corresponds to the conditions mentioned above and an $\mathrm{Hb}$ concentration of $10 \mathrm{~mm} /$ liter blood, it can be calculated that these $\mathrm{pH}_{\mathrm{i}}$ changes correspond to $0.21 \mathrm{mEq}$ $\mathrm{H}^{+} / \mathrm{mM} \mathrm{O}_{2}$ in adult erythrocytes and to $0.17 \mathrm{mEq}$ $\mathrm{H}^{+} / \mathrm{mM} \mathrm{O}_{2}$ in fetal erythrocytes. These intracellular amounts of protons are not "seen" by measurements of the $\Delta \mathrm{H}+/ \Delta \mathrm{O}_{2}$ ratio in whole blood at constant $\mathrm{pH}_{\mathrm{p}}$. Thus, the $\mathrm{pH}_{\mathrm{i}}$ shift caused by oxygenation at constant $\mathrm{pH}_{\mathrm{p}}$ influences largely the $\Delta \mathrm{H}+/ \Delta \mathrm{O}_{2}$ ratio obtained in whole blood and could account by itself for the discrepancy between the adult whole blood Bohr effect and the HbA solutions Bohr effect. These figures are perhaps not strictly accurate because of the uncertainties associated with the $\mathrm{pH}_{\mathrm{i}}$ determinations and the buffer value of the $\mathrm{Hb}$ molecule inside the erythrocyte. Nevertheless, it is evident that the value of the Bohr effect obtained by measurements in whole blood does not permit inferences about the quantitative role of the various intraerythrocytic components on the Bohr effect.

However, this empiric $\Delta \mathrm{H}+/ \Delta \mathrm{O}_{2}$ ratio obtained in whole blood has a practical implication, because it represents the magnitude of the correction needed when partly desaturated blood is analyzed by the Astrup method [9]. According to the present results, this correction depends on the $\mathrm{P}_{\mathrm{CO}_{2}}$ and on the $\mathrm{pH}_{\mathrm{p}}$, the extreme values being between 0.33 and $0.50 \mathrm{mEq} \mathrm{H}+1$ $\mathrm{mM} \mathrm{O}_{2}$ in the ranges studied. When an unique correction factor of $0.50 \mathrm{mEq} \mathrm{H}+/ \mathrm{mM} \mathrm{O}_{2}$ is used as proposed by Siggaard-Andersen for adult blood [9], the maximal error involved is $0.17 \mathrm{mEq} \mathrm{H}^{+} / \mathrm{mM} \mathrm{O}_{2}$, in terms of $\mathrm{P}_{\mathrm{CO}_{2}}$ at the most $2 \mathrm{~mm} \mathrm{Hg}$ at an initial oxygen saturation level $\left(\mathrm{S}_{\mathrm{O}_{2}}\right)$ of $60 \%$ and a $\mathrm{Hb}$ concentration of $10 \mathrm{~mm} /$ liter. This error is of minor importance for the determinations of the blood acid-base status in

Copyright @ 1973 International Pediatric Research Foundation, Inc. clinical routine. However, when a scientific aim is pursued, it may be useful to remember that the fetal $\Delta \mathrm{H}+/ \Delta \mathrm{O}_{2}$ ratio differs from the adult one under some conditions.

\section{Summary}

This study shows that, at $[\mathrm{BE}]$ of 0 and $+10 \mathrm{mEq} /$ liter, the fetal metabolic buffer value and the fetal Bohr effect differ from the adult ones. The causes and the practical implications of these differences between fetal and adult blood are discussed.

\section{References and Notes}

I. Antonini, E., Wyman, J., Brunori, M., Fronticelli, C., Bucci, E., Reichlin, M., and Rossi-Fanelli, A.: The oxygen Bohr effect of human fetal hemoglobin. Arch. Biochem. Biophys., 108: 569 (1964).

2. Arczynskn, W., AND Held, D. R.: The amount of $\mathrm{H}^{+}$released on iso-pH oxygenation of human whole blood. Resp. Physiol., 12: 7 (1971).

3. Arczynskn, W., and Prod'hom, L. S.: The buffer values and the Bohr effect of human fetal and adult whole blood in vitro in an acid range. Pediat. Res., $7: 126$ (1973).

4. BAUER, C.: Reduction of the carbon dioxide affinity of human haemoglobin solutions by 2,3-diphosphoglycerate. Resp. Physiol., 10: 10 (1970).

5. Baver, C., AND Schröder, E.: Carbamino compounds of haemoglobin in human adult and fetal blood. J. Physiol., 227: 457 (1972).

6. Karmann, U., Arczynska, W., and Held, D. R.: A contribution to the study of the whole blood Bohr effect in the alkaline range. Resp. Physiol., 13: 261 (1971).

7. Rossi-Bernardi, L., and Roughton, F. J. W.: The specific influence of carbon dioxide and carbamate compounds on the buffer power and Bohr effects in human haemoglobin solutions. J. Physiol., 189: 1 (1967).

8. SiggaARd-ANDERSEN, O.: The pH- $\log \mathrm{P}_{\mathrm{CO}_{2}}$ blood acid-base nomogram revised. Scand. J. Clin. Lab. Invest., 14: 598 (1962).

9. SiggaARd-Andersen, O., AND ENGEL, K.: A new acid-base nomogram: An improved method for the calculation of the relevant blood acid-base data. Scand. J. Clin. Lab. Invest., 12: 177 (1960).

10. Sigganrd-Andersen, O., and Salling, N.: Oxygen-linked hydrogen ion binding of human hemoglobin: Effects of carbon dioxide and 2,3-diphosphoglycerate. II. Studies on whole blood. Scand. J. Clin. Lab. Invest., 27: 361 (1971).

11. I wish to thank Miss G. Krings and Miss A. Ney for skillful technical assistance. The helpful advice of Professor L. S. Prod'hom (Service de Pédiatrie, Lausanne, Switzerland) and Professor D. R. Held (Institut de Physiologie, Fribourg, Switzerland) is gratefully acknowledged.

12. This work was supported by the Swiss National Foundation for Scientific Research, Grant no. 3.564.71.

13. Requests for reprints should be addressed to: W. ArcZYNSKA, M.D., Service de Pédiatrie, Hôpital Cantonal Universitaire, Lausanne, Switzerland.

14. Accepted for publication August 8, 1973. 